\title{
Predictors of treatment success in smoking cessation with varenicline combined with nicotine replacement therapy $v$. varenicline alone
}

\author{
F Noor, ${ }^{1}$ MB ChB, MSc; C F N Koegelenberg, ${ }^{1}$ MB ChB, MMed (Int), FCP (SA), FRCP (UK), Cert Pulm (SA), PhD; T M Esterhuizen, ${ }^{2}$ MSc; \\ E M Irusen, ${ }^{1} \mathrm{MB} \mathrm{ChB}, \mathrm{FCP}(\mathrm{SA}), \mathrm{PhD}$
}

${ }^{1}$ Division of Pulmonology, Department of Medicine, Stellenbosch University and Tygerberg Academic Hospital, Cape Town, South Africa
${ }^{2}$ Centre for Evidence-based Health Care, Stellenbosch University, Cape Town, South Africa

Corresponding author: C F N Koegelenberg (coeniefn@sun.ac.za)

\begin{abstract}
Background. Identification of the predictors of treatment success in smoking cessation may help healthcare workers to improve the effectiveness of attempts at quitting.

Objective. To identify the predictors of success in a randomised controlled trial comparing varenicline alone or in combination with nicotine replacement therapy (NRT).

Methods. A post-hoc analysis of the data of 435 subjects who participated in a 24-week, multicentre trial in South Africa was performed. Logistic regression was used to analyse the effect of age, sex, age at smoking initiation, daily cigarette consumption, nicotine dependence, and reinforcement assessment on abstinence rates at 12 and 24 weeks. Point prevalence and continuous abstinence rates were self-reported and confirmed biochemically with exhaled carbon monoxide readings.

Results. The significant predictors of continuous abstinence at 12 and 24 weeks on multivariate analysis were lower daily cigarette consumption (odds ratio (OR) 1.86, 95\% confidence interval (CI) $1.21-2.87, p=0.005$ and OR 1.83, 95\% CI 1.12 - 2.98, $p=0.02$, respectively) and older age (OR 1.52, 95\% CI $1.00-2.31, p=0.049$ and OR 1.79, 95\% CI $1.13-2.84, p=0.01$, respectively). There was no difference in the predictors of success in the univariate analysis, except that older age predicted point prevalence abstinence at 12 weeks (OR 1.47, $95 \%$ CI 1.00 $-2.15, p=0.049$ ). The findings were inconclusive for an association between abstinence and lower nicotine dependence, older age at smoking initiation and positive reinforcement.

Conclusion. Older age and lower daily cigarette consumption are associated with a higher likelihood of abstinence in patients using varenicline, regardless of the addition of NRT.
\end{abstract}

S Afr Med J 2018;108(1):45-49. DOI:10.7196/SAMJ.2018.v108i1.12671

Tobacco dependence is a global epidemic and a major preventable cause of morbidity and mortality. The World Health Organization reported that nearly 6 million tobacco-related deaths occur annually. ${ }^{[1]}$ Despite the well-known benefits of smoking cessation, it remains a challenge for many smokers who attempt to quit. Approximately $70 \%$ of smokers want to discontinue smoking; ${ }^{[2]}$ however, only $3-5 \%$ of those who attempt to do so without assistance remain abstinent in the long term ${ }^{[3]}$ Behavioural interventions and pharmacotherapy are effective methods in smoking cessation, ${ }^{[4]}$ and when combined, are even more efficacious. ${ }^{[5]}$ Commonly used pharmacotherapies include nicotine replacement therapy (NRT), bupropion and varenicline. All have been proven to be efficacious to varying degrees.

Studies investigating factors that predict smoking cessation success have identified the following: male gender, older age, older age at initiation of smoking, lower nicotine dependency, lower exhaled carbon monoxide levels, fewer cigarettes smoked per day and higher confidence with regard to quitting (self-efficacy). Heavier smokers and smokers with a high nicotine dependency in particular are more likely to continue smoking. ${ }^{[6-15]}$ A tobacco user who smokes at least 20 cigarettes per day is generally considered to be a heavy smoker. The level of nicotine dependence may be assessed with the Fagerström test for nicotine dependence (FTND) - a frequently used questionnaire scored out of 10 , with a score of at least 7 denoting high dependency ${ }^{[16]}$ Reasons for successful cessation include health concerns and the high cost of cigarettes. ${ }^{[17]}$ The motivation for continued smoking may also contribute - smoking for pleasure or reward (positive reinforcement), or to relieve a negative state (negative reinforcement). ${ }^{[18]}$

A recent study reported that combining varenicline and bupropion improved abstinence rates in heavier smokers and in persons with a high nicotine dependency. ${ }^{[19]}$ This suggests that combination therapies may improve success rates in these difficult groups.

In a recent randomised controlled trial (RCT), we established that varenicline combined with NRT was more effective than varenicline alone, with a favourable safety profile. ${ }^{[20]}$ We performed a post-hoc analysis of the data from the original RCT to identify the independent predictors of successful abstinence at 12 and 24 weeks after the target quit date. The objective was to assist healthcare workers to select interventions according to the characteristics of the individual smoker to improve their chances of success.

\section{Methods}

Study design

We performed a post-hoc analysis of a study dataset prospectively collected from April 2011 to October 2012 at seven sites throughout South Africa (SA). The study was conducted in accordance with the principles outlined in the Declaration of Helsinki, and local and international Good Clinical Practice guidelines. Ethical approval was obtained from the Health Research Ethics Committee of Stellenbosch University (ref. no. S15/02/029). The original study methods and 
outcomes have been described elsewhere. ${ }^{[20]}$ In the original study, 446 adult smokers were randomised to receive either varenicline $1 \mathrm{mg}$ twice daily with active nicotine patches $15 \mathrm{mg}$ per day (combination therapy) or varenicline twice daily with placebo patches (monotherapy) for 12 weeks, and were followed up for a further 12 weeks.

\section{Study procedures and assessment}

In the current analysis, all randomised participants who were administered at least one dose of both medications were included in the study population. They were categorised by specific baseline characteristics, including age, sex, age at smoking initiation, cigarette consumption per day, nicotine dependence as measured by the FTND and motivation for continued smoking using the reinforcement assessment, and were followed up until weeks 12 and 24 . The measures of cessation included 7-day point prevalence abstinence, referring to the preceding 7 days, and continuous abstinence - a prolonged period of at least 4 weeks before the assessment date. At week 12, the 7-day point prevalence abstinence rate (PPAR) and the 4-week continuous abstinence rate (CAR) for weeks 9 - 12 were evaluated. At week 24, the 7-day PPAR and CAR for weeks 9 - 24 were also measured. Abstinence from tobacco was self-reported using the Nicotine Use Inventory (NUI), which evaluates tobacco or nicotine use (other than that provided) since the last contact and the preceding 7 days. This was biochemically confirmed by exhaled carbon monoxide measurements of $\leq 10$ parts per million. Participants who missed the visits at weeks 12 and 24 were considered smokers at those time points, and those who discontinued the study or were lost to follow-up were also considered smokers.

\section{Statistical aspects}

The data were analysed using Stata version 13.1 (StataCorp., USA). Univariate logistic regression was used to do a crude analysis of the entire study population to identify predictors of abstinence for each of the four outcomes. Participants for whom the relevant baseline data were missing, were excluded from that particular category for univariate analysis as per protocol.

Multivariate logistic regression was used to measure the association between all the baseline characteristics and abstinence rates at weeks 12 and 24, adjusting for the treatment received. To include all participant data in the models for multivariate analysis, missing data were coded as missing and included in the models as a separate category. Odds ratios (ORs) and $95 \%$ confidence intervals (CIs) were calculated and statistical significance was indicated at $p<0.05$.

\section{Results}

A total of 446 participants were randomised, 435 of whom were included -216 in the combination therapy arm, and 219 in the monotherapy arm. Their baseline characteristics have been reported elsewhere. ${ }^{[20]}$ No statistically significant differences in baseline predictors were found between the participants in the active treatment group and those in the placebo group. Missing baseline data were minimal and comparable across treatment arms $(<2 \%)$.

The short-term (7-day point prevalence) and long-term (continuous) abstinence rates in each treatment arm according to baseline characteristics are shown in Table 1. In keeping with our previous findings, the active group had a higher abstinence rate than the placebo group across all categories. ${ }^{[20]}$

In the univariate analysis conducted at 12 and 24 weeks, CARs were significantly higher in light smokers than in heavy smokers at both time points, and in older participants than in those $<50$ years of age at the 24-week time point (Table 2). These associations remained significant in the multivariate analysis. The only predictor of PPAR was younger age - at 12 weeks. In the sample, heavily nicotine-dependent participants were more likely to continue smoking than those who were less nicotine dependent; however, this difference was not statistically significant, indicating no population differences. No other factors significantly predicted successful smoking cessation, including sex, age at smoking initiation and motivation for continued smoking, i.e. the reinforcement assessment.

The multivariate analysis did not markedly change the ORs for all variables, except for identifying younger age as a predictor of the 12-week CAR.

Participants who started smoking after the age of 20 had a relatively poorer response on varenicline alone (CAR 22.2\%) than those on combination therapy (CAR 39.1\%) $(p<0.01)$.

\section{Discussion}

The original study confirmed that the addition of NRT improved smoking cessation success at both time points. The only other significant predictors of success identified in the current analysis were older age and lower daily cigarette consumption.

The reasons for smoking cessation, self-efficacy (a participant's belief in his/her ability to succeed) and level of motivation were not assessed, but it may be that older persons are more likely to be motivated to quit because of health concerns. Younger persons may consider future opportunities to quit and be less committed or motivated. ${ }^{[11]}$ Preparedness for the challenges of tobacco abstinence was not assessed, but quit attempts were well supported by smoking cessation counselling during all visits before and after quitting.

The finding that heavier smokers had lower abstinence rates than those who smoked fewer cigarettes per day is in keeping with previous research ${ }^{[7,8,10-12]}$ however, it contrasts with a recent study, where a combination of varenicline and bupropion improved abstinence in heavy smokers and in those who were more nicotine dependent. ${ }^{[19]}$ This may be due to the average daily cigarette consumption in this study population being lower, as was the average FTND. The data from our study did not suggest that combination therapy (varenicline and NRT) conferred any benefit to heavy and more-dependent smokers.

Unlike previous research, which indicated that lower levels of nicotine dependence were associated with increased abstinence, ${ }^{[7,9-11,14]}$ we did not observe this. We investigated whether highly dependent smokers would benefit more, but unexpectedly there were fewer patients with high dependence. Studies have also found that men are more likely to abstain than women ${ }^{[7-10,12]}$ however, we could not confirm this - perhaps because we had a greater number of female participants.

Despite the original study findings in favour of the addition of NRT to varenicline, we found little difference in the ORs between univariate and multivariate analyses, suggesting that the addition of nicotine replacement to varenicline did not markedly alter the predictors of abstinence. Baseline characteristics that predicted success in participants who received varenicline alone were found to be similar to those of the group who received both varenicline and NRT.

There may be other factors that contribute to smoking cessation success. Genetic studies of variations in the nicotine-receptor gene cluster CHRNA5-CHRNA3-CHRNB4 found that although smokers with the high-risk haplotype had a heightened response to pharmacotherapy, they were more likely to relapse than the low-risk group. ${ }^{[21]}$ Recent research also found that the therapeutic response to a nicotine patch and varenicline is influenced by the nicotine 
Table 1. Abstinence rates in each treatment arm according to baseline characteristics

\begin{tabular}{|c|c|c|c|c|c|c|}
\hline \multirow[b]{2}{*}{$\begin{array}{l}\text { Baseline } \\
\text { characteristics }\end{array}$} & \multirow[b]{2}{*}{$\begin{array}{l}\text { Treatment } \\
\text { arm }\end{array}$} & \multirow[b]{2}{*}{ Total } & \multicolumn{2}{|c|}{12 weeks } & \multicolumn{2}{|c|}{24 weeks } \\
\hline & & & $\begin{array}{l}\text { 7-day PPAR, } \\
n \text { (\%) }\end{array}$ & $\begin{array}{l}\text { CAR } 9 \text { - } 12 \text { weeks, } \\
n(\%)\end{array}$ & $\begin{array}{l}\text { 7-day PPAR, } \\
n(\%)\end{array}$ & $\begin{array}{l}\text { CAR 9 - } 24 \text { weeks, } \\
n(\%)\end{array}$ \\
\hline \multicolumn{7}{|l|}{ Age, years } \\
\hline \multirow[t]{2}{*}{$\geq 50$} & Active & 94 & $61(64.89)$ & $52(55.32)$ & $50(53.19)$ & $40(42.55)$ \\
\hline & Placebo & 90 & $35(38.89)$ & $28(31.11)$ & $23(25.56)$ & $18(20.00)$ \\
\hline \multirow[t]{2}{*}{$<50$} & Active & 122 & $55(45.08)$ & $47(38.52)$ & $44(36.07)$ & $31(25.41)$ \\
\hline & Placebo & 129 & $52(40.31)$ & $42(32.56)$ & $40(31.01)$ & $24(18.60)$ \\
\hline \multicolumn{7}{|l|}{ Sex } \\
\hline \multirow[t]{2}{*}{ Male } & Active & 87 & $43(49.43)$ & $38(43.68)$ & $34(39.08)$ & $28(32.18)$ \\
\hline & Placebo & 83 & $31(37.35)$ & $25(30.12)$ & $24(28.92)$ & $15(18.07)$ \\
\hline \multirow[t]{2}{*}{ Female } & Active & 129 & $73(56.59)$ & $61(47.29)$ & $60(46.51)$ & $43(33.33)$ \\
\hline & Placebo & 136 & $56(41.18)$ & 45 (33.09) & $39(28.68)$ & $27(19.85)$ \\
\hline \multicolumn{7}{|c|}{ Cigarettes/day, $n$} \\
\hline \multirow{2}{*}{$\geq 20$} & Active & 85 & $45(52.94)$ & 35 (41.18) & $34(40.00)$ & $24(28.24)$ \\
\hline & Placebo & 93 & $31(33.33)$ & $20(21.51)$ & $21(22.58)$ & $12(12.90)$ \\
\hline \multirow[t]{2}{*}{$<20$} & Active & 131 & $71(54.20)$ & $64(48.85)$ & $60(45.80)$ & $47(35.88)$ \\
\hline & Placebo & 126 & $56(44.44)$ & $50(39.68)$ & $42(33.33)$ & $30(23.81)$ \\
\hline \multicolumn{7}{|c|}{$\begin{array}{l}\text { Level of nicotine } \\
\text { dependence }\end{array}$} \\
\hline \multirow[t]{2}{*}{ FTND $\geq 7$} & Active & 12 & $4(33.33)$ & $3(25.00)$ & $3(25.00)$ & $2(16.67)$ \\
\hline & Placebo & 15 & $4(26.67)$ & $4(26.67)$ & $3(20.00)$ & $3(20.00)$ \\
\hline \multirow[t]{2}{*}{ FTND $<7$} & Active & 202 & $111(54.95)$ & $95(47.03)$ & 89 (44.06) & $68(33.66)$ \\
\hline & Placebo & 201 & 83 (41.29) & $66(32.84)$ & $59(29.35)$ & $39(19.40)$ \\
\hline \multicolumn{7}{|l|}{$\begin{array}{l}\text { Age at smoking } \\
\text { initiation, years }\end{array}$} \\
\hline \multirow[t]{2}{*}{$\geq 20$} & Active & 46 & $29(63.04)$ & $24(52.17)$ & $24(52.17)$ & $18(39.13)$ \\
\hline & Placebo & 54 & $24(44.44)$ & $20(37.04)$ & $19(35.19)$ & $12(22.22)$ \\
\hline \multirow[t]{2}{*}{$<20$} & Active & 170 & $87(51.18)$ & $75(44.12)$ & $70(41.18)$ & $53(31.18)$ \\
\hline & Placebo & 165 & $63(38.18)$ & $50(30.30)$ & $44(26.67)$ & $30(18.18)$ \\
\hline \multicolumn{7}{|l|}{$\begin{array}{l}\text { Reinforcement } \\
\text { assessment }^{\dagger}\end{array}$} \\
\hline \multirow[t]{2}{*}{ NR } & Active & 44 & $23(52.27)$ & $20(45.45)$ & $21(47.73)$ & $16(36.36)$ \\
\hline & Placebo & 52 & $18(34.62)$ & $15(28.85)$ & $13(25.00)$ & $10(19.23)$ \\
\hline \multirow[t]{2}{*}{ PR } & Active & 54 & $29(53.70)$ & $24(44.44)$ & $20(37.04)$ & $15(27.78)$ \\
\hline & Placebo & 49 & $24(48.98)$ & $16(32.65)$ & $18(36.73)$ & $10(20.41)$ \\
\hline \multirow[t]{2}{*}{$\mathrm{NR}+\mathrm{PR}$} & Active & 95 & $53(55.79)$ & $44(46.32)$ & $42(44.21)$ & $31(32.63)$ \\
\hline & Placebo & 97 & $40(41.24)$ & $35(36.08)$ & $29(29.90)$ & $20(20.62)$ \\
\hline \multirow[t]{2}{*}{ N/A } & Active & 20 & $10(50.00)$ & $10(50.00)$ & $8(40.00)$ & $8(40.00)$ \\
\hline & Placebo & 19 & $5(26.32)$ & $4(21.05)$ & $3(15.79)$ & $2(10.53)$ \\
\hline
\end{tabular}

metabolite ratio (NMR), a genetically influenced biomarker measuring the ratio of two nicotine metabolites produced during smoking. ${ }^{[22]}$ Participants with a normal metabolism had better abstinence rates when receiving varenicline, whereas those with a slow metabolism fared better on nicotine patches. Genetic factors and NMR were not assessed in the current study, but correcting for this ratio may change the predictors of success. From a behavioural science perspective, another recent study found that financial incentives were associated with successful smoking cessation and that harnessing the individual's aversion to loss in a cessation programme may encourage a change in smoking behaviour. $^{[23]}$

Our study has limited generalisability, as we enrolled mostly healthy persons without a history of psychiatric illness in the 
Table 2. Predictors of smoking cessation success at weeks 12 and 24

\begin{tabular}{|c|c|c|c|c|c|c|c|c|}
\hline \multirow[b]{3}{*}{ Predictors } & \multicolumn{4}{|c|}{ Univariate } & \multicolumn{4}{|c|}{ Multivariate $^{\star}$} \\
\hline & \multicolumn{2}{|c|}{ 7-day PPAR } & \multicolumn{2}{|c|}{ CAR } & \multicolumn{2}{|c|}{ 7-day PPAR } & \multicolumn{2}{|c|}{ CAR } \\
\hline & OR $(95 \% \mathrm{CI})$ & $p$-value & OR $(95 \% \mathrm{CI})$ & $p$-value & OR $(95 \% \mathrm{CI})$ & $p$-value & OR $(95 \% \mathrm{CI})$ & $p$-value \\
\hline \multicolumn{9}{|c|}{12 weeks (CAR 9 - 12 weeks) } \\
\hline $\begin{array}{l}\text { Combination therapy } \\
\text { v. monotherapy }\end{array}$ & $\begin{array}{l}1.76 \\
(1.20-2.57)\end{array}$ & $0.004^{\varsigma}$ & $\begin{array}{l}1.80 \\
(1.22-2.66)\end{array}$ & $0.003^{\varsigma}$ & - & - & - & - \\
\hline $\begin{array}{l}\text { Age }(\geq 50 \text { v. }<50) \text {, } \\
\text { years }\end{array}$ & $\begin{array}{l}1.47 \\
(1.00-2.15)\end{array}$ & $0.049^{\varsigma}$ & $\begin{array}{l}1.40 \\
(0.95-2.07)\end{array}$ & 0.09 & $\begin{array}{l}1.49 \\
(0.99-2.23)\end{array}$ & 0.056 & $\begin{array}{l}1.52 \\
(1.00-2.31)\end{array}$ & $0.049^{\S}$ \\
\hline Sex (male v. female) & $\begin{array}{l}0.81 \\
(0.55-1.20)\end{array}$ & 0.29 & $\begin{array}{l}0.88 \\
(0.59-1.31)\end{array}$ & 0.54 & $\begin{array}{l}0.83 \\
(0.55-1.24)\end{array}$ & 0.36 & $\begin{array}{l}0.93 \\
(0.62-1.41)\end{array}$ & 0.74 \\
\hline $\begin{array}{l}\text { Cigarettes/day } \\
(<20 \mathrm{v} . \geq 20), n^{\dagger}\end{array}$ & $\begin{array}{l}1.31 \\
(0.89-1.93)\end{array}$ & 0.17 & $\begin{array}{l}1.78 \\
(1.19-2.67)\end{array}$ & $0.005^{\lessgtr}$ & $\begin{array}{l}1.29 \\
(0.85-1.96)\end{array}$ & 0.23 & $\begin{array}{l}1.86 \\
(1.21-2.87)\end{array}$ & $0.005^{\varsigma}$ \\
\hline FTND $(<7 \text { v. } \geq 7)^{\ddagger}$ & $\begin{array}{l}2.20 \\
(0.94-5.15)\end{array}$ & 0.07 & $\begin{array}{l}1.90 \\
(0.79-4.6)\end{array}$ & 0.15 & $\begin{array}{l}1.80 \\
(0.74-4.35)\end{array}$ & 0.19 & $\begin{array}{l}1.39 \\
(0.55-3.52)\end{array}$ & 0.48 \\
\hline $\begin{array}{l}\text { Age started smoking } \\
(\geq 20 \mathrm{v} .<20) \text {, years }\end{array}$ & $\begin{array}{l}1.39 \\
(0.89-2.18)\end{array}$ & 0.15 & $\begin{array}{l}1.32 \\
(0.84-2.08)\end{array}$ & 0.23 & $\begin{array}{l}1.25 \\
(0.78-1.99)\end{array}$ & 0.36 & $\begin{array}{l}1.17 \\
(0.73-1.89)\end{array}$ & 0.51 \\
\hline $\begin{array}{l}\text { Reinforcement } \\
\text { assessment, PR v. NR }\end{array}$ & $\begin{array}{l}1.42 \\
(0.81-2.49)\end{array}$ & 0.22 & $\begin{array}{l}1.11 \\
(0.62-1.97)\end{array}$ & 0.73 & $\begin{array}{l}1.32 \\
(0.74-2.34)\end{array}$ & 0.35 & $\begin{array}{l}1.04 \\
(0.58-1.89)\end{array}$ & 0.89 \\
\hline $\begin{array}{l}\text { Reinforcement assess- } \\
\text { ment, NR + PR v. NR }\end{array}$ & $\begin{array}{l}1.26 \\
(0.77-2.06)\end{array}$ & 0.36 & $\begin{array}{l}1.22 \\
(0.74-2.02)\end{array}$ & 0.44 & $\begin{array}{l}1.25 \\
(0.75-2.08)\end{array}$ & 0.39 & $\begin{array}{l}1.23 \\
(0.73-2.08)\end{array}$ & 0.43 \\
\hline \multicolumn{9}{|c|}{24 weeks (CAR 9 - 24 weeks) } \\
\hline $\begin{array}{l}\text { Combination therapy } \\
\text { v. monotherapy }\end{array}$ & $\begin{array}{l}1.91 \\
(1.28-2.84)\end{array}$ & $0.001^{5}$ & $\begin{array}{l}2.06 \\
(1.33-3.20)\end{array}$ & $0.001^{\varsigma}$ & - & - & - & - \\
\hline $\begin{array}{l}\text { Age }(\geq 50 \text { v. }<50) \text {, } \\
\text { years }\end{array}$ & $\begin{array}{l}1.31 \\
(0.88-1.94)\end{array}$ & 0.18 & $\begin{array}{l}1.64 \\
(1.07-2.53)\end{array}$ & $0.03^{\varsigma}$ & $\begin{array}{l}1.41 \\
(0.93-2.15)\end{array}$ & 0.11 & $\begin{array}{l}1.79 \\
(1.13-2.84)\end{array}$ & $0.01^{\varsigma}$ \\
\hline Sex (male v. female) & $\begin{array}{l}0.87 \\
(0.58-1.30)\end{array}$ & 0.49 & $\begin{array}{l}0.94 \\
(0.61-1.47)\end{array}$ & 0.80 & $\begin{array}{l}0.94 \\
(0.62-1.44)\end{array}$ & 0.79 & $\begin{array}{l}1.02 \\
(0.64-1.62)\end{array}$ & 0.94 \\
\hline $\begin{array}{l}\text { Cigarettes/day } \\
(<20 \text { v. } \geq 20), n^{\dagger}\end{array}$ & $\begin{array}{l}1.47 \\
(0.98-2.21)\end{array}$ & 0.06 & $\begin{array}{l}1.69 \\
(1.07-2.65)\end{array}$ & $0.02^{\varsigma}$ & $\begin{array}{l}1.38 \\
(0.90-2.14)\end{array}$ & 0.14 & $\begin{array}{l}1.83 \\
(1.12-2.98)\end{array}$ & $0.02^{5}$ \\
\hline FTND $(<7 \text { v. } \geq 7)^{\ddagger}$ & $\begin{array}{l}2.03 \\
(0.80-5.15)\end{array}$ & 0.14 & $\begin{array}{l}1.59 \\
(0.59-4.31)\end{array}$ & 0.36 & $\begin{array}{l}1.59 \\
(0.60-4.18)\end{array}$ & 0.35 & $\begin{array}{l}1.21 \\
(0.43-3.45)\end{array}$ & 0.72 \\
\hline $\begin{array}{l}\text { Age started smoking } \\
(\geq 20 \mathrm{v} .<20) \text {, years }\end{array}$ & $\begin{array}{l}1.46 \\
(0.93-2.31)\end{array}$ & 0.10 & $\begin{array}{l}1.30 \\
(0.79-2.13)\end{array}$ & 0.30 & $\begin{array}{l}1.42 \\
(0.88-2.28)\end{array}$ & 0.15 & $\begin{array}{l}1.17 \\
(0.70-1.97)\end{array}$ & 0.54 \\
\hline $\begin{array}{l}\text { Reinforcement } \\
\text { assessment, PR v. NR }\end{array}$ & $\begin{array}{l}1.07 \\
(0.60-1.90)\end{array}$ & 0.83 & $\begin{array}{l}0.86 \\
(0.46-1.63)\end{array}$ & 0.65 & $\begin{array}{l}1.02 \\
(0.56-1.86)\end{array}$ & 0.95 & $\begin{array}{l}0.82 \\
(0.42-1.58)\end{array}$ & 0.55 \\
\hline $\begin{array}{l}\text { Reinforcement assess- } \\
\text { ment, NR + PR v. NR }\end{array}$ & $\begin{array}{l}1.07 \\
(0.64-1.78)\end{array}$ & 0.80 & $\begin{array}{l}0.97 \\
(0.56-1.69)\end{array}$ & 0.93 & $\begin{array}{l}1.08 \\
(0.64-1.83)\end{array}$ & 0.78 & $\begin{array}{l}0.99 \\
(0.56-1.76)\end{array}$ & 0.98 \\
\hline 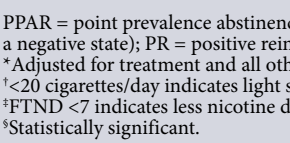 & $\begin{array}{l}\text { :CAR }=\text { con } \\
\text { ment (smoki } \\
\text { tors in the m } \\
\text { rrs; } 220 \text { cigare }\end{array}$ & $\begin{array}{l}\text { nure) } \\
\text { ndical } \\
\text { steare }\end{array}$ & $\begin{array}{l}\mathrm{R}=\text { odds ratio; } \\
\text { ot applicable (ne } \\
\text { smokers. } \\
\text { dependence. }\end{array}$ & $\begin{array}{l}=\text { Fage } \\
\text { d to qu }\end{array}$ & & & reinforceme & g to \\
\hline
\end{tabular}

previous 2 years. Our findings are nonetheless similar to those of studies resembling real-life situations. ${ }^{[7,15]}$ The overall attrition rate of $36.1 \%$ may have affected the outcomes, but attrition was similar across the two treatment arms $(33.3 \%$ in the active arm v. $38.8 \%$ in the placebo arm) and is comparable to that in previous studies. The results may have been underestimated by defining all participants who withdrew, defaulted on visits or were lost to follow-up as smokers, but this is in keeping with previous research and the high likelihood of treatment failure in such subjects. ${ }^{[19]}$ We did not assess the effect of the financial cost of continued smoking on abstinence rates and smoking behaviour, but as our study was conducted during a worldwide economic recession, this may have influenced the predictors of successful cessation attempts. We could also not specifically evaluate the potential impact of the level of education and smoking status of participants' partners on smoking cessation.

\section{Conclusion}

Advanced age and lower daily cigarette consumption are associated with a higher likelihood of abstinence in patients who receive varenicline, regardless of the addition of NRT. Future studies should consider genetic factors, NMR, effect of personal resources, financial implications and local tobacco regulations, and possibly also novel ways of incentivising subjects. 
Acknowledgements. Prof. Eric D Bateman, Prof. Richard N van Zyl-Smit, Drs Axel Bruning, John A O’Brien, Clifford Smith, Mohamed S AbdoolGaffar and Shaunagh Emanuel, who contributed to the data collection of the original study.

Author contributions. All authors contributed to the study concept and design. FN had full access to all study data and performed analyses and interpretation with the assistance of EMI and TME. FN drafted the manuscript with support from all authors. The study was supervised by EMI.

Funding. None.

Conflicts of interest. None.

1. World Health Organization. World Health Organization tobacco factsheet No. 339. http://www.who. int/mediacentre/factsheets/fs339/en/ (accessed 21 November 2017)

. Centers for Disease Control and Prevention. Quitting smoking among adults - United States, 2001 - 2010. MMWR Morb Mortal Wkly Rep 2011;60(44):1513-1519. https://doi.org/10.15585/mmwr.mm6552al

3. Hughes JR, Keely J, Naud S. Shape of the relapse curve and long-term abstinence among untreated smokers. Addiction 2004;99(1):29-38. https://doi.org/10.1111/j.1360-0443.2004.00540.x

4. Hartmann-Boyce J, Stead LF, Cahill K, Lancaster T. Efficacy of interventions to combat tobacco addiction: Cochrane update of 2013 reviews. Addiction 2014;109(9):1414-1425. https://doi.org/10.1111/add.12633

5. Stead LF, Lancaster T. Combined pharmacotherapy and behavioural interventions for smoking cessation. Cochrane Database Syst Rev 2012;(10):CD008286. https://doi.org/10.1002/14651858.cd008286.pub2

6. Caponnetto P, Polosa R. Common predictors of smoking cessation in clinical practice. Respir Med 6. Caponnetto P, Polosa R. Common predictors of smoking cessatio
2008;102(8):1182-1192. https://doi.org/10.1016/j.rmed.2008.02.017

7. Dorner TE, Trostl A, Womastek I, Groman E. Predictors of short-term success in smoking cessation Dorner TE, Trostl A, Womastek I, Groman E. Predictors of short-term success in smoking cessation
in relation to attendance at a smoking cessation program. Nicotine Tob Res 2011;13(11):1068-1075. in relation to attendance at a smoking
https://doi.org/10.1093/ntr/ntr179

8. Hymowitz N, Cummings KM, Hyland A, Lynn WR, Pechacek TF, Hartwell TD. Predictors of smoking cessation in a cohort of adult smokers followed for five years. Tob Control 1997;6(Suppl 2):S57-S62. https://doi.org/10.1136/tc.6.suppl_2.s57

9. Iliceto P, Fino E, Pasquariello S, D’Angelo Di Paola ME, Enea D. Predictors of success in smoking cessation among Italian adults motivated to quit. J Subst Abuse Treat 2013;44(5):534-540. https://doi. org/10.1016/j.jsat.2012.12.004

10. Monso E, Campbell J, Tonnesen P, Gustavsson G, Morera J. Sociodemographic predictors of success in smoking intervention. Tob Control 2001;10(2):165-169. https://doi.org/10.1136/tc.10.2.165
11. Myung SK, Seo HG, Park S, et al. Sociodemographic and smoking behavioral predictors associated with smoking cessation according to follow-up periods: A randomized, double-blind, placebocontrolled trial of transdermal nicotine patches. J Korean Med Sci 2007;22(6):1065-1070. https://doi. controlled trial of transdermal nic

12. Schuck K, Otten R, Kleinjan M, Bricker JB, Engels RC. Predictors of cessation treatment outcome and treatment moderators among smoking parents receiving quitline counselling or self-help material. Prev Med 2014;69:126-131. https://doi.org/10.1016/j.ypmed.2014.09.014

13. Smit ES, Hoving C, Schelleman-Offermans K, West R, de Vries H. Predictors of successful and unsuccessful quit attempts among smokers motivated to quit. Addict Behav 2014;39(9):1318-1324. https://doi.org/10.1016/j.addbeh.2014.04.017

14. Stolz D, Scherr A, Seiffert B, et al. Predictors of success for smoking cessation at the workplace: A longitudinal study. Respiration 2014;87(1):18-25. https://doi.org/10.1159/000346646

15. Wee LH, Shahab L, Bulgiba A, West R. Stop smoking clinics in Malaysia: Characteristics of attendees and predictors of success. Addict Behav 2011;36(4):400-403. https://doi.org/10.1016/j. addbeh.2010.11.011

16. Huang CL, Lin $\mathrm{HH}$, Wang $\mathrm{HH}$. Evaluating screening performances of the Fagerstrom tolerance questionnaire, the Fagerstrom test for nicotine dependence and the heavy smoking index among Taiwanese male smokers. J Clin Nurs 2008:17(7):884-890. https://doi.org/10.1111/j.1365-2702.2007.02054.X

17. Kaleta D, Korytkowski P, Makowiec-Dabrowska T, Usidame B, Bak-Romaniszyn L, Fronczak A. Predictors of long-term smoking cessation: Results from the global adult tobacco survey in Poland (2009 - 2010). BMC Public Health 2012;12(1):1020. https://doi.org/10.1186/1471-2458-12-1020

18. Fagerström K, Carlos J, Mochales J, Hans G. Can smoking for positive or negative reinforcemen together with dependence help us better diagnose smokers? J Smoking Cessation 2007;2(1):5-7. https://doi.org/10.1375/jsc.2.1.5

19. Ebbert JO, Hatsukami DK, Croghan IT, et al. Combination varenicline and bupropion SR for tobaccodependence treatment in cigarette smokers: A randomized trial. JAMA 2014;311(2):155-163. https:/ doi.org/10.1001/jama.2013.283185

20. Koegelenberg CF, Noor F, Bateman ED, et al. Efficacy of varenicline combined with nicotine replacement therapy vs varenicline alone for smoking cessation: A randomized clinical trial. JAMA 2014;312(2):155-161. https://doi.org/10.1001/jama.2014.7195

21. Chen L, Baker TB, Piper ME, et al. Interplay of genetic risk factors (CHRNA5-CHRNA3-CHRNB4) and cessation treatments in smoking cessation success. Am J Psychiatry 2012;169(7):735-742. https:// doi.org/10.1176/appi.ajp.2012.11101545

22. Lerman C, Schnoll RA, Hawk LW Jr, et al. Use of the nicotine metabolite ratio as a genetically informed biomarker of response to nicotine patch or varenicline for smoking cessation: A randomised, doubleblind placebo-controlled trial. Lancet Respir Med 2015;3(2):131-138. https://doi.org/10.1016/s22132600(14)70294-2

23. Halpern SD, French B, Small DS, et al. Randomized trial of four financial-incentive programs for smoking cessation. N Engl J Med 2015;372(22):2108-2117. https://doi.org/10.1056/nejmoal414293

Accepted 26 September 2017. 